\section{PSYCHOAKUSTICKÉ A PSYCHOVIZUÁLNÍ TESTY PRO HODNOCENÍ HLASU}

\section{Tomáš Kulhánek, Marek Frič}

\begin{abstract}
Abstrakt
Příspěvek představí systém pro psychoakustické a psychovizuální testy na adrese https://psychoacoustic.hamu.cz/. Usnadňuje subjektivní hodnocení hlasů a jiných stimulů a s tím spojeného výzkumu v oboru hlasové vědy a jiných. Systém propojuje stimuli uložené jako soubory nemalé velikosti $v 1$ ) datovém úložišti. Stimuli jsou zvukové, obrazové nebo video soubory. Systém umožňuje vytvářet definici testu, která popisuje obrazovky, na každé obrazovce může být jeden nebo více stimulů a úkoly, které má uživatel splnit při hodnocení stimulů. Systém generuje unikátní URL adresu testu, která se může distribuovat uživatelům - hodnotitelům.

Systém navíc agreguje výsledky testování, tj. ohodnocení různými uživateli a poskytuje data $\mathrm{k}$ dalšímu statistickému zpracování.

Systém se nyní používá k subjektivnímu hodnocení stupně různých zvukových abnormalit hlasu a k trénování hlasových expertů a terapeutů. Taktéž se použíá pro kvalitativní vyhodnocování hlasových cvičení nejen u pacientů, ale i u hlasových profesionálů (herců, zpěváků, ...). Navíc je nově využíván i pro nácvik hodnocení obrazových a video sekvencí hlasivek pořízených laryngoskopem a hodnocení stimulů vysokorychlostní kamerou nebo pomocí metody videokymografie.
\end{abstract}

\section{Úvod}

Subjektivní poslechové testy a hodnocení zvukových stimulů je důležitou metodou $v$ oboru psychoakustiky pro posuzování a vyhodnocování vlastností, které jsou obtížně měřitelné objektivně. Např. vyhodnotit jak je daný hlas nebo zvuk celkově plný, drsný, dyšný nebo nestabilní. Záleží na vnímání (percepci) hodnotitele, na kvalifikaci a zkušenostech hodnotitele.

Poslechových testů se účastní statistický soubor hodnotitelů - respondentů. Pro minimalizaci některých systematických chyb se upravuje i pořadí zvukových stimulů pro jednotlivé respondenty náhodně nebo pseudonáhodně.

Příprava poslechového testu může probíhat ručně např. formou "ručního" spouštění zvuků experimentátorem a zaznamenání hodnocení hodnotitele "na papír". Poslechový test může být taktéž naprogramován v nějakém programovacím jazyce, prípadně využít specializované nebo obecné dotazníkové aplikace, které pouští zvuky hodnotiteli předem naprogramovaným způsobem.

Ve výzkumném centru hudební akustiky HAMU jsme v minulosti vyvinuly Systém LiTEd, jako specializovanou aplikaci, která je spuštěna experimentátorem na kalibrovaném počítači se zvukovým výstupem a hodnotitel test prochází a hodnotí stimuli dle naprogramovaného pořadí stimulů a dotazů [1].

Pro možnost prípravy a provádění testů na webu distančním způsobem je možné použít nespecializované, obecné webové dotazníkové systémy, např. Google Surveys, SurveyMonkey, Microsoft Forms, aj.

$V$ rámci projektu "PsychotestEditor" a spolupráce s 1. lékařskou fakultou Univerzity Karlovy a sdružením CESNET vznikla odlehčená verze systému LiTED, která umožňuje přípravu a provádění psychoakustických testů na webu distančním způsobem. Programování testů je založeno nikoliv na prípravě webových stránek ve formě HTML, ale na definování stránek testu v interně vyvinutém doménově specifickém jazyce, který je pak v prohlížeči uživatele interpretován a zobrazena je konečná podoba jednotlivé stránky v HTML se stimuli a dotazníkem. Výsledek hodnocení je zaznamenán $v$ databázi a zpřístupněn experimentátorovi pro další statistické zpracování[2][5][7].

$\checkmark$ tomto příspěvku představíme rozšířenou verzi systému pro "Psychoakustické a psychovizuální testy a editor" (PAVE), který propojuje datové úložiště experimentátora $s$ testy a stimuli s webovou aplikací pro testování dostupnou na adrese https:// psychoacoustic.hamu.cz/.

\section{Propojení dat}

Stimuli, tj. datové soubory se zvuky, obrazy a videi jsou uložena v datovém úložišti experimentátora mimo server odkud je obsluhován web https://psychoacoustic.hamu.cz. Přes protokoly WEBDAV a HTTP se datové soubory prostřednictvím naprogramovaného testu zpř́stupňuje respondentům k poslechu nebo ke shlédnutí. Prohlížeč tak jen zprostředkuje přístup ke stimulům, datové úložiště (typicky v jiné doméně) musí podporovat tzv. Cross-origin resource s (CORS), což je bezpečnostní standard, který reguluje přistup $\mathrm{k}$ datovým zdrojům z jiného místa, než je doména datového úložiště.

Výsledek, tj. zaznamenané reakce a odpovědi respondenta jsou uložené opět $v$ datové úložišti, ale mohou být jinde dle volby experimentátora testu. Architektura systému je schematicky znázorněna níže. Rozhraní WEBDAV1, WEBDAV2 a WEBDAV3 jsou 3 různé URL, které obsluhují protokol WEBDAV - rozšíření protokolu HTTP o možnost obsluhovat data. Z protokolu WEBDAV použíáme PROPFIND pro získání seznamu souborů a adresářů $v$ datovém úložišti.

V současnosti je podporováno datové úložiště Owncloud v implementaci poskytované sdružením CESNET pro všechny studenty a akademické pracovníky českých vysokých škol na adrese https://owncloud.cesnet.cz. Nevýhodou je jeho dostupnost jen pro české uživatele. Ve vývoji je podpora obdobného datového úložiště, jenž je dostupné na evropské úrovni. Zvažována je integrace se službou B2DROP, která je vyvíjena a udržována z evropských zdrojů pod iniciativou EOSC (European Open Science Cloud). Taky zvažujeme komerční úložiště, které umožní používat systém experimentátorům bez účtu v akademické oblasti.

Kroky pro prípravu a realizaci testu

1. Připojení datového úložiště

2. Příprava definice testu

3. Generování URL testu a distribuce respondentům

4. Realizace testu respondenty

5. Vyhodnocení nasbíraných výsledků

\section{Přípojení datového uložiště}

Experimentátor nejprve musí připojit datové úložiště, v implementaci OWNCLOUD je možné vytvořit 3 druhy sdílených odkazů, jenž podporují protokol WEBDAV s právy pro zápis a čtení (pro experimentátora pro editaci a úpravu testu), s právy pro čtení (pro respondenta umožňující čtení stimulů definici testu) a s právy pro slepý zápis (pro respondenta umožňující uložení odpovědi respondenta na test).

\section{Příprava definice testu}

Experimentátor vytvoří nový test, nebo vybere ze seznamu existujících testů a je mu otevřen webový editor, který kontroluje syntaxi doménově specifického jazyka definující obrazovky testu. 


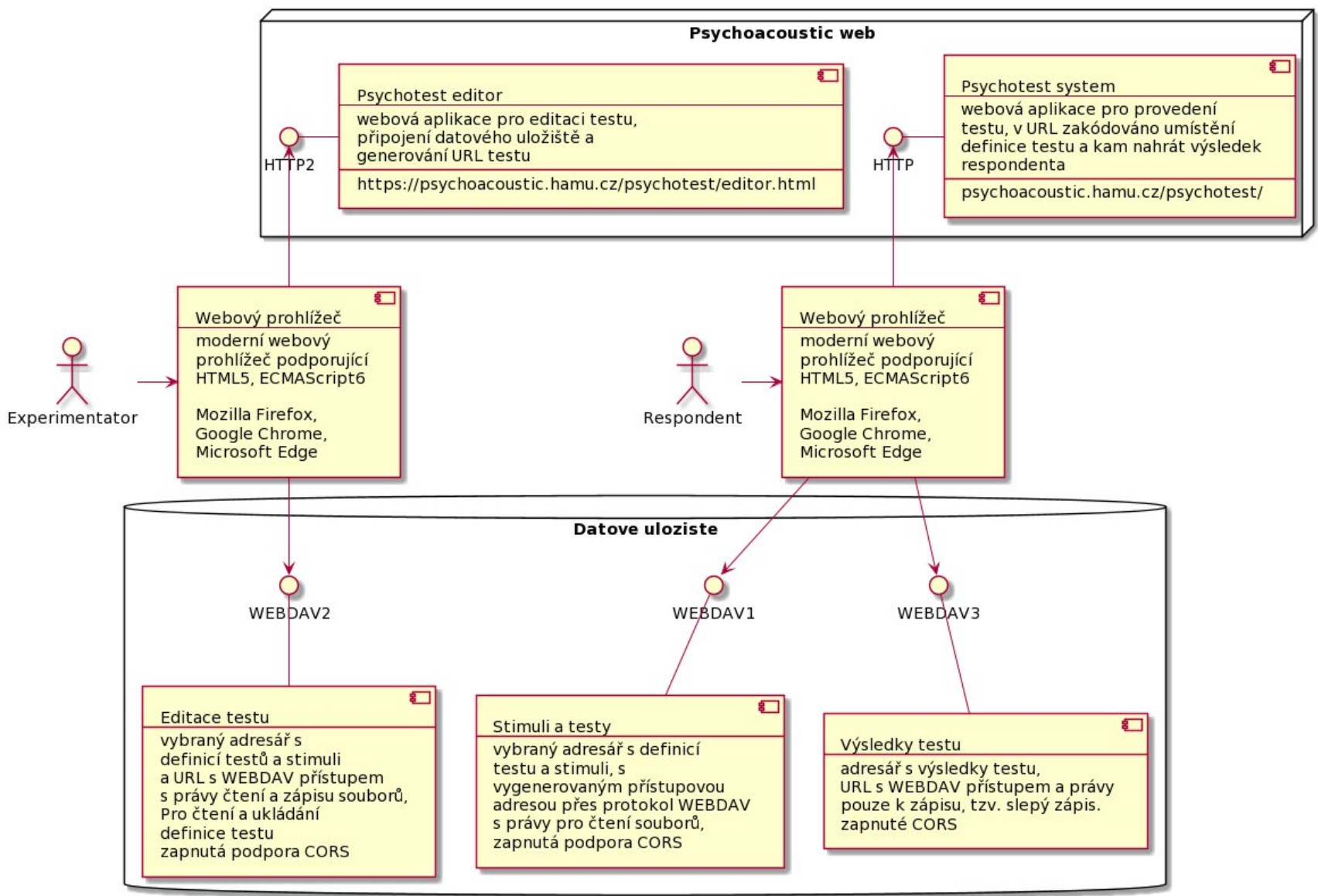

Obrázek 1 - Architektura systému

Na obrázku je definice testu pro hodnocení vlastností hlasů. Drsnost (roughness), dyšnost (breathiness), slabost (asthenicity), hlasové napětí (strain) a nestabilita (instability).

Doménově specifický jazyk umožňuje definovat vzhled obrazovek, je možné do něj vložit části kódu HTML, nebo stylu v CSS. Díky tomu lze využít bohatost současného standardu HTML5 a CSS3 podporovanou většinou prohlížečů.

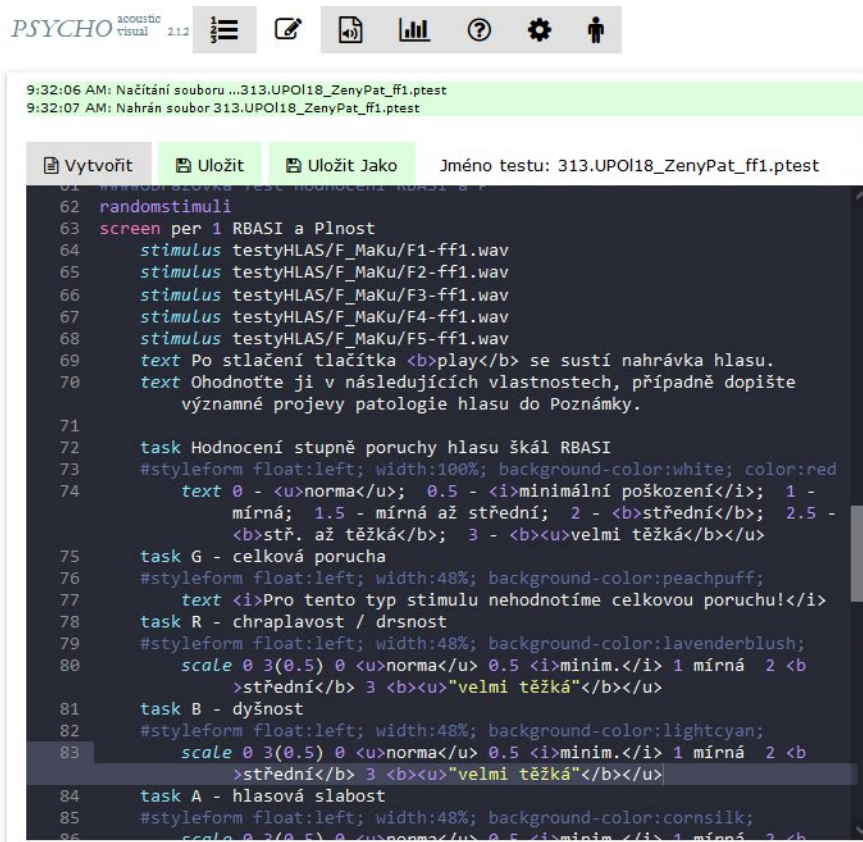

Obrázek 2

\section{Realizace testu respondenty}

Po vytvoření testu je možné vygenerovat unikátní URL, které v sobě obsahuje zakódované umístění stimulů a definice testu. Toto URL je možné rozeslat respondentům pro distanční vyhodnocení.

Na obrázku je náhled obrazovky číslo 4 z celkem 41, které umožní přehrát zvuk a respondent vyhodnocuje výše zmíněné vlastnosti.

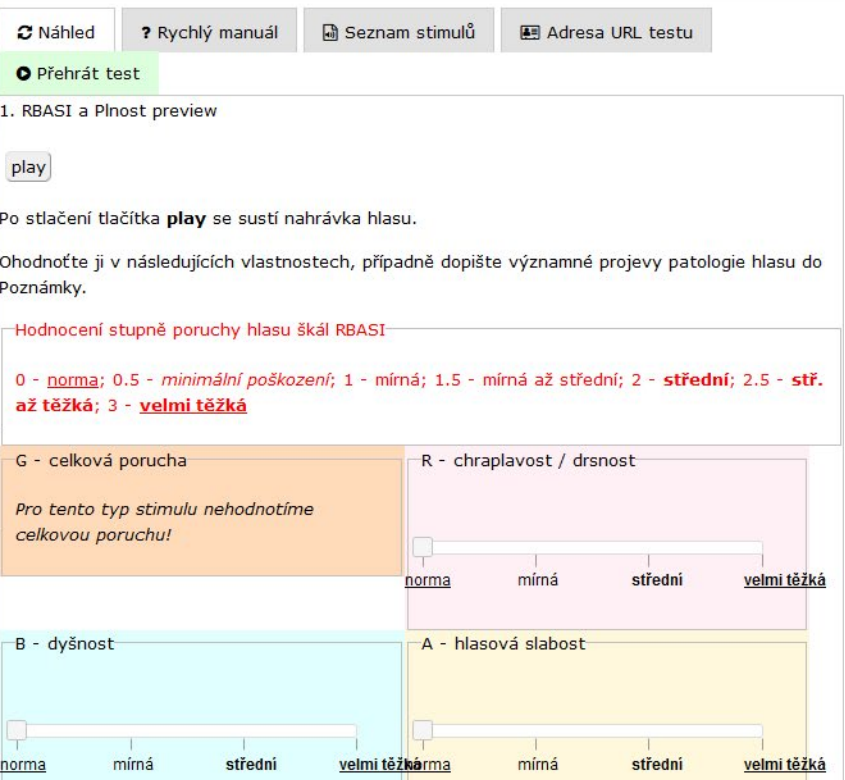




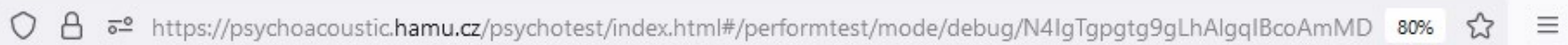

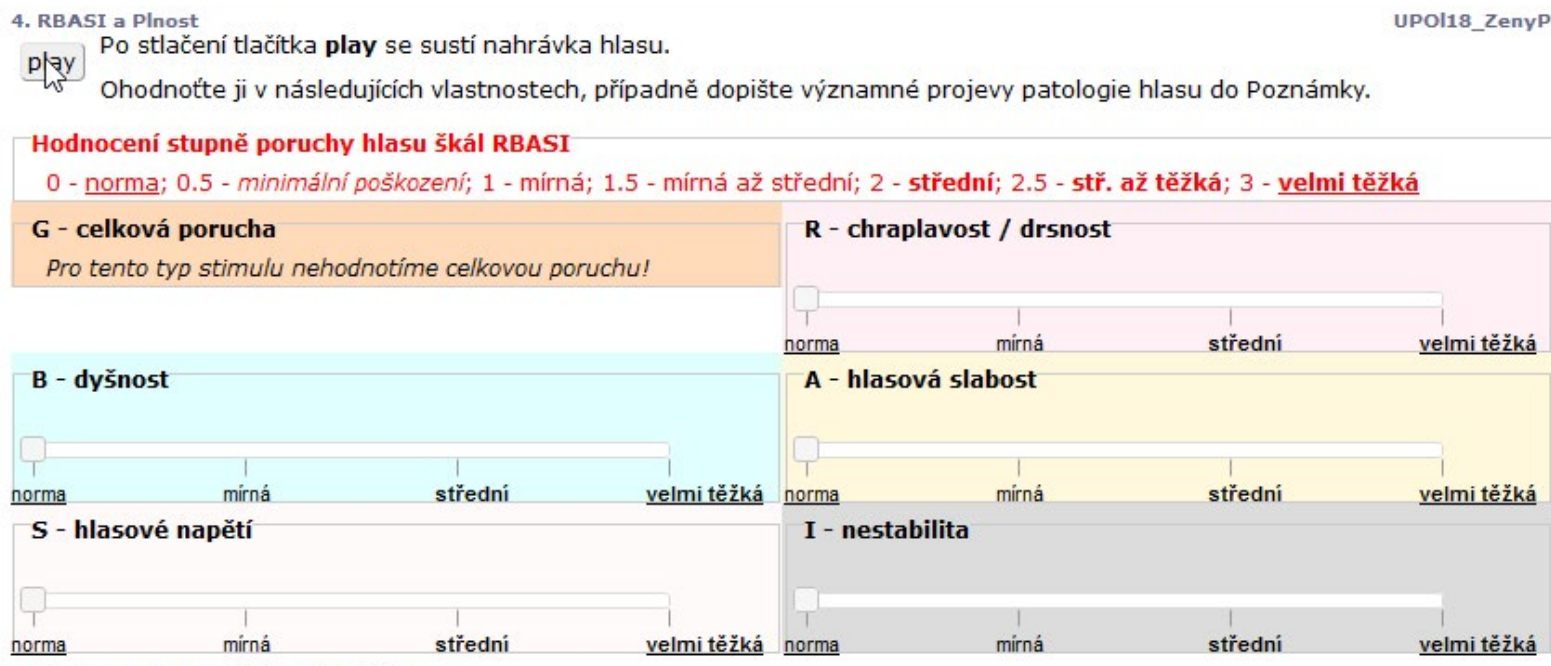

Hodnocení plnosti / znělosti hlasu

Vlastnost plnost / znělost reprezentuje bohatost a zdravost hlasu, je opakem slabého, nebo ostrého hlasu.

Plnost / znělost

velmi slabá střednẽ oslabená vormálnè znèlý velmi zvučný

Poznámky

Popište připadně jiné významné vlastnosti zvuku, zejména chrakterizujte nestabilitu

Obrázek 3

\section{Zpracování odpovědí}

Odpovědi respondentů, kteří vyplnili test se uloží na definované místo experimentátorem, z něj je pak možné výsledky sloučit a exportovat do různých formátů, podporovány jsou formáty XLSX (MS Excel 2007+ XML formát), ODS (Open Document Spreadsheet) a CSV (Comma Separated Value). Výsledky jsou hrubé a statistika a další zpracování jsou už čistě záležitostí experimentátora.

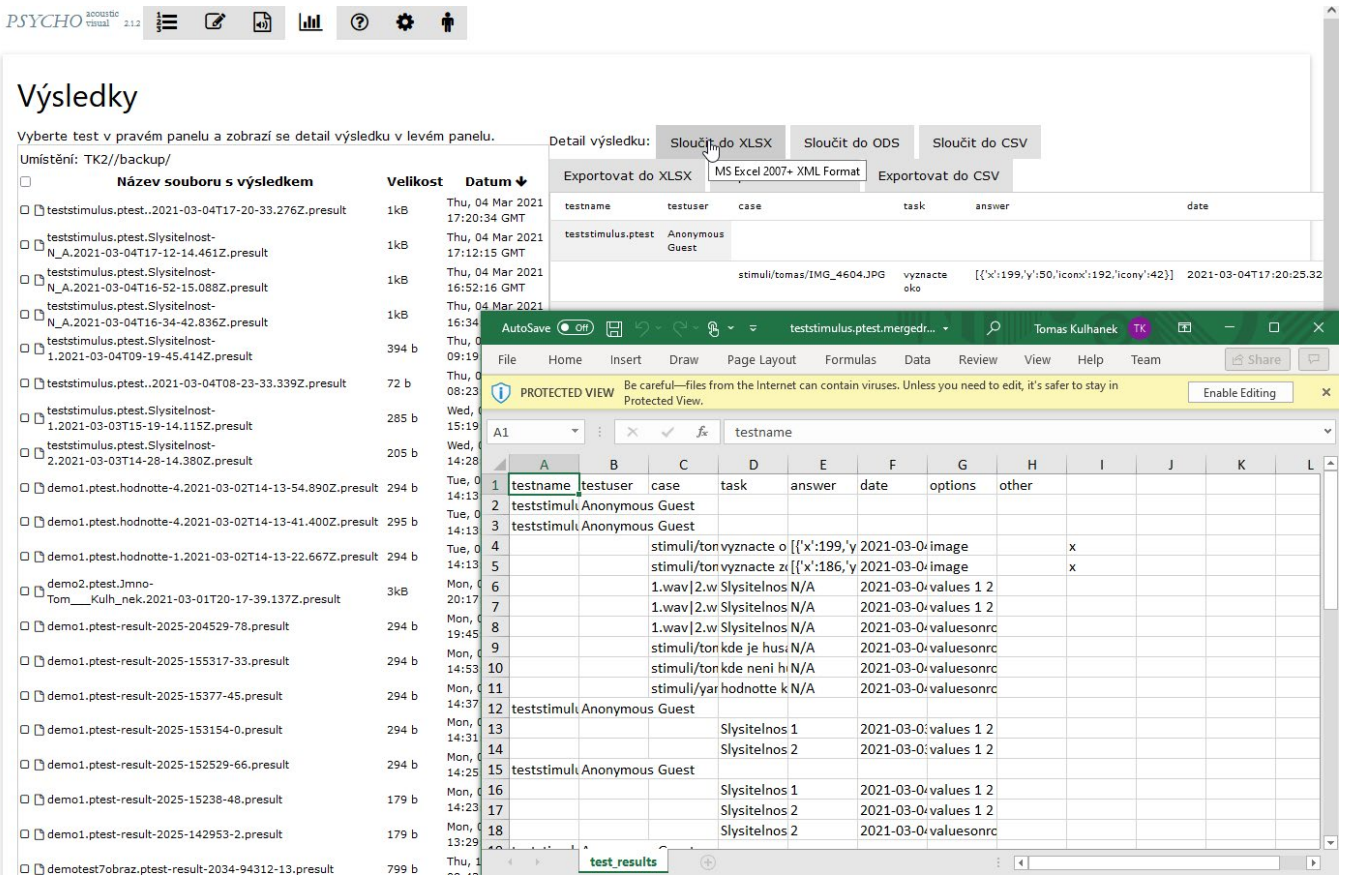




\section{Výsledky}

Systém psychotestu umožňuje propojit datové uložiště s rozsáhlou sbírkou zvukových nebo video stimulů. Jedním z požadavků bylo, aby experimentátor nemusel dávat přístup ke svým datům administrátorům systému psychotestu, ale jen svým respondentům.

Systém se používá pro výzkum a nácvik percepčních testů jako jednou z metod pro diagnostiku hlasových poruch[3] [4], pro ohodnocení uměleckého projevu různých interpretů [6] nebo výzkum jaké je vnímání emocí při poslechu indické klasické hudby i u posluchače západoevropského kulturního okruhu[8].

\section{Poděkování}

Tato práce vznikla za podpory grantu Fondu rozvoje CESNET č. 667 ročník 2020/1 a taktéž za podpory projektu IP DKR AMU "Subjektivní a objektivní aspekty kvality hudebních zvuků".

\section{Reference}

[1.] Technologický list 36 Z. Otčenášek, J. Štěpánek, J. Prokop, M. Frič, J. Hrb, LiTEd - Software pro editaci, provádění a vyhodnocování poslechových testů - MARC HAMU, Praha 2010.

[2.] Technologcký list 82 T. Kulhánek, M. Frič, J. Otčenášek, Software pro tvorbu percepčních testů na webovém rozhraní - MARC HAMU, Praha 2016

[3.] KUČERA, M., FRIČ M., FRITZLOVÁ, K., HALÍŘ M. Vokologie I - FunkČní diagnostika a léčba hlasových poruch. Akademie múzických umèní v Praze, 2019. ISBN: 978-80-270-6200-3

a.Nácvikové percepčni testy uvedené v multimediální príloze monografie, jejichž webovou verzi pro hodnocení habituálního čtení lze najít v sekci Nácvikové testy

[4.] KUČERA, M., FRIČ M., FRITZLOVÁ, K., HALÍŘ M., DVOŘÁKOVÁ, E., ČEŠKOVÁ O. Základy vokologie - diagnostika, prevence a rehabilitace hlasu. Odborný seminář s workshopy. 11. - 12. Řínna 2019, Galerie HAMU.

[5.] Frič, M. PerceptualTest \& ResponseAnalysis (PTRA)-program pro provádění základních percepčních testů a analýzu jejich výsledků. Praha: MARC-Technologický list čís. 93 Výzkumné centrum hudební akustiky HAMU, 2018.

[6.] FRIČ, M., BERTI, A., OTČENÁŠEK, J. Percepční hodnocení vlastností pěveckého provedení koloraturní árie. Musicologica Brunensia, 2019, 54(1), s. 187-222. https://doi.org/10.5817/MB2019-1-1

[7.] Frič, M. Perceptual evaluation of voice quality modification in pitch, loudness and voice type changes in dysphonic women. In PAN-EUROPEAN VOICE CONFERENCE 2019 Voicing Science and Experience Book of Abstracts, $s 28$.

[8.] Reindl, T., Frič, M., Hruška, V. Rágy a emoce-hudebně psychologické aspekty severoindických rág, Hudební věda 57(1),2020,s. 52-79

\section{Kontakt}

Mgr. Tomáš Kulhánek, Ph.D. Oddělení biokybernetiky

U nemocnice 5

12853 Praha 2

e-mail:tmkulhanek@gmail.com

\section{RNDr. Marek Frič, Ph.D.}

Výzkumné centrum hudební akustiky Hudební a taneční fakulta

Akademie múzických umění v Praze

Malostranské náměstí 259/12

11800 Praha 1

e-mail: marek.fric@hamu.cz 